\title{
THE ANALYSIS OF CARBON MONOXIDE POISONING CASES PRESENTED TO THE EMERGENCY DEPARTMENT OF A UNIVERSITY HOSPITAL
}

\author{
Bir Üniversite Hastanesi Acil Servisine Başvuran \\ Karbon Monoksit Zehirlenmesi Olgularının Analizi
}

\author{
Abuzer COŞKUN ${ }^{1}$, Afşin Emre KAYIPMAZ ${ }^{2}$, Sedat ÖZBAY ${ }^{1}$, Osman Mahir OKUR ${ }^{1}$, \\ Şevki Hakan EREN ${ }^{3}$, Cemil KAVALCI ${ }^{2}$ \\ ${ }^{1}$ Department of Emergency, Numune Hospital, SIVAS \\ ${ }^{2}$ Department of Emergency, Baskent University Faculty of Medicine, ANKARA \\ ${ }^{3}$ Department of Emergency, Cumhuriyet University Faculty of Medicine, SIVAS
}

\begin{abstract}
* This study was presented in an oral session at $5^{\text {th }}$ Eurasian Congress on Emergency Medicine $\& 12^{\text {th }}$ Turkish Emergency Medicine Congress.
\end{abstract}

\section{ABSTRACT}

Introduction: Carbon monoxide poisoning is one of the most leading poisoning causing death through worldwide, although its exact incidence is yet to be determined. Carbon monoxide is a colorless and odorless gas that binds to hemoglobin and cellular oxidative enzymes with a higher affinity than oxygen, causing tissue hypoxia. Hypoxia of heart and nervous system cells leads to neuropsychiatric and cardiological signs and symptoms. In this study, we aimed to investigate the demographic characteristics of the carbon monoxide poisonings occurring in patients presenting to the emergency department. We also aimed to determine the clinical characteristics, and the factors affecting the mortality.

Material and Methods: We retrospectively reviewed the demographic and clinical characteristics of 1013 patients who admitted to our adult emergency department and were diagnosed with carbon monoxide poisoning for a period of two years. We recorded and analyzed age, gender, season of presentation, hospital admission rate, sources of poisoning, symptoms at admission, mortality rate, and carboxyhemoglobin and cardiac Troponin-I levels.

Results: The mean age of the study population was $36.2 \pm 16.2$ years. $70.5 \%$ of the patients were admitted in winter seasons. $66.1 \%$ of the patients' poisoning source was water heater and stove. The most frequent symptoms were nausea, headache, and dizziness. On multilogistic regression analysis the death rate was significantly correlated with age and cardiac Troponin I level.

Conclusion: Our results indicate that accidental carbon monoxide poisonings continue to be an important public health problem in regions with cold winter seasons. We believe that intensifying efforts for public education and efficient control of resources of poisoning are the key steps to prevent carbon monoxide poisonings.

Keywords: Epidemiology, carbon-monoxide, poisoning

\section{Öz}

Giriş: Karbonmonoksit zehirlenmesi, insidansı kesin olarak bilinmemekle birlikte dünya çapında ölüme sebep olan başlıca zehirlenmelerden birisidir. Karbonmonoksit, hemoglobine ve hücresel oksidatif enzimlere oksijenden daha yüksek bir afiniteyle bağlanarak doku hipoksisine neden olan renksiz ve kokusuz bir gazdır. Kalp ve sinir sistemi hücrelerindeki hipoksi, nöropsikiyatrik ve kardiyolojik belirti ve bulgularının oluşmasına yol açar. Bu çalışmada karbonmonoksit zehirlenmesi nedeniyle acil servise başvuran olguların demografik ve klinik özelliklerini araştırmayı amaçladık.

Gereç ve Yöntem: Erişkin acil servisimize iki yıllık bir süre zarfinda başvurup karbonmonoksit zehirlenmesi tanısı alan 1013 hastanın demografik ve klinik özelliklerini retrospektif olarak gözden geçirdik. Hastaların yaş, cinsiyet, başvuru mevsimi, hastane yatış oranı, zehirlenmenin kaynağı, başvuru belirtileri, mortalite oran1, karboksihemoglobin ve Troponin I seviyeleriyle ilgili bilgileri kayıt ve analiz ettik.

Bulgular: Çalışma popülâsyonunun ortalama yaşı $36.2 \pm 16.2$ 'di. Hastaların \%70,5'i kış mevsiminde başvuru yapmıştı. Hastaların \%66,1'inin zehirlenme kaynağı sıcak su 1sitıcısı, gazla çalışan sobalardı. En sık bulgular bulantı, baş ağrısı ve sersemlik hissiydi. Multilojistik regresyon analizinde ölüm hızı ile yaş ve kardiyak Troponin I düzeyi arasında anlamlı ilişki olduğu tespit edildi.

Sonuç: Çalışmamızın sonuçları, karbonmonoksit zehirlenmesinin zorlu kış koşullarının hâkim olduğu bölgelerde halen önemli bir halk sağlığı problemi olduğunu ortaya koymaktadır. Toplumun eğitimi ve zehirlenme kaynaklarının ile karbonmonoksit zehirlenmesinin önlenebilir olacağını düşünmekteyiz.

Anahtar Kelimeler: Epidemiyoloji, karbonmonoksit, zehirlenme 


\section{INTRODUCTION}

Carbon monoxide poisoning is one of the leading poisonings causing death worldwide, although its exact incidence is yet to be determined $(1,2)$. It is a colorless and odorless gas that binds to hemoglobin and cellular oxidative enzymes with a higher affinity than oxygen, causing tissue hypoxia. Hypoxia of heart and nervous system cells leads to neuropsychiatric and cardiological signs and symptoms (3). Patients diagnosed with carbon monoxide poisoning are discharged from the emergency department in about $90 \%$ of cases (4). However, we believe that recommending patients to apply to cardiology, neurology, and psychiatry clinics at the time of discharge from the emergency department is important in regard to prevention of lateterm complications.

We aimed in this study to investigate the demographic characteristics of the carbon- monoxide poisonings occurring in patients presenting to the emergency department. We also aimed to determine their clinical characteristics, and the factors affecting the mortality.

\section{MATERIALS AND METHODS}

We conducted our study after ethics committee approval no 2012-12/09 in 04.12.2012. We retrospectively reviewed the demographic and clinical characteristics of 1013 patients who presented to the Emergency Department of Sivas Cumhuriyet University Hospital and were diagnosed with carbon monoxide poisoning between 2005 and 2007. We recorded and analyzed age, gender, season of presentation, hospital admission rate, sources of poisoning, symptoms at admission, mortality rate, and carboxyhemoglobin $(\mathrm{COHb})$ and Troponin I levels.

\section{RESULTS}

The mean age of the study population was $36.2 \pm 16.2$ years. Demographics of patients with carbon monoxide poisoning are summarized in Table 1.

Table 1: Demographics of patients with carbon monoxide poisoning

\begin{tabular}{lc}
\hline Variables & $\mathbf{n}(\boldsymbol{\%})$ \\
\hline Gender & $611(60.3)$ \\
Female & $402(39.7)$ \\
Male & \\
Season of presentation & $126(12.4)$ \\
Spring & $60(5.9)$ \\
Summer & $113(11.2)$ \\
Fall & $714(70.5)$ \\
Winter & \\
Source of poisoning & $670(66.1)$ \\
Water heater-gas stove & $343(33.9)$ \\
Barbecue-Coal burning stoves &
\end{tabular}

$70.5 \%$ of the patients were admitted in winter seasons. $66.1 \%$ of the patients' poisoning source was water heater-gas stove. Symptoms of patients are showed in Table 2.

Table 2: Symptoms of patients with carbon monoxide poisoning

\begin{tabular}{lc}
\hline Symptom & n (\%) \\
\hline Headache & $635(62.7)$ \\
Dizziness & $441(43.5)$ \\
Nausea & $650(64.2)$ \\
Vomiting & $322(31.8)$ \\
Altered consciousness & $199(19.6)$ \\
Coma & $44(4.3)$ \\
Death & $31(3.1)$ \\
\hline
\end{tabular}


The most frequent symptoms were nausea (64.2\%), headache $(62.7 \%)$ and dizziness $(43.5 \%)$. The mean admission $\mathrm{COHb}$ and cardiac Troponin I levels were 13.4 \pm 7.1 and $0.2 \pm 0.9$, respectively. No significant difference was found between the $\mathrm{COHb}$ levels of both genders $(\mathrm{p}=0.078)$. There was no significant difference between $\mathrm{COHb}$ levels with respect to the season of presentation $(\mathrm{p}=0.537)$. There was also no significant correlation between $\mathrm{COHb}$ and cardiac Troponin I levels. On multilogistic regression analysis the death rate was significantly correlated with age and cardiac Troponin I level. The hospitalization rate of carbon monoxide poisoning patients was $13.8 \%(n=140)$ and discharge from emergency rate was \%86.2 $(n=873)$.

\section{DISCUSSION}

Carbon monoxide poisoning is one of the leading causes of poisoning-related death (2). In Turkey, according to the 2010 official data, 10154 cases of poisoning were reported, of which 39 resulted in mortality (5). In addition to the risk of death, carbon monoxide poisoning can also cause neurological and cardiac injury $(6,7)$. In this study, we found a correlation between age, admission cardiac Troponin I level, and mortality rate. Abass et al. showed that cardiac Troponin I levels were significantly correlated with $\mathrm{COHb}$ levels and despite 6 hours treatment, cardiac Troponin I levels were elevated significantly (8). Henry et al. proved that $37 \%$ of moderate-severe carbon monoxide poisoning patients had cardiac injury. $61.1 \%$ of these patients had abnormal cardiac Troponin I levels. 38\% of cardiac injury patients were died (9). In our study, the correlation between mortality and cardiac Troponin I levels were found compatible with the literature. El Sayed et al reported that 55.6\% of their cases were male and the mean age of the study population was $33.8 \pm 1.5$ years. In our study, on the other hand, $60.3 \%$ of the cases were female and the mean age of the overall population was $36.2 \pm 16.2$ years. Ninety-two point six percent of the patients in that study were discharged from the emergency department while $86.2 \%$ of our patients were discharged from the emergency department (10). Ghosh et al reported 2463 cases of non-fire induced, accidental carbon monoxide poisoning between 2001 and 2010 in England. Presentations most commonly occurred in winter months, as was the case in our study. The authors indicated that carbon monoxide poisoning was a preventable cause of poisoning (11). In our study 1013 patients were exposed to carbon monoxide poisoning. We observed 506 cases on an average annually while that study from England reported a carbon monoxide poisoning number 2463 for over one decade. This study was conducted in a region where winter seasons are cold. We suggest that it is necessary to escalate public health efforts (especially educational activities) to prevent carbon monoxide poisonings that occur with carbon monoxide sources such as water heaters, gas stoves, barbecues, and coal burning stoves. Emami-Razavi and colleagues reported that educational activities should be intensified to prevent carbon monoxide poisonings in Iran, a country close to our region. Similar to our findings, the most common 5 symptoms in that study were nausea, headache, dizziness, altered consciousness, and coma. In accordance with our study, water heaters and gas stoves were the most common carbon monoxide sources (12). Ku et al from Taiwan reported 19 deaths among 261 poisoning cases $(7.2 \%)$. We observed a death rate of $3.1 \%(n=31)$ in a total of 1013 cases. While a suicidal attempt was the reason of poisoning in $49.4 \%$ of the cases in that study, none of our patients were poisoned in a suicide attempt (13).

We detected a significant correlation between the admission Troponin I level, age, and mortality rate. Our results indicate that accidental carbon monoxide poisoning continue to be an important public health problem in regions with harsh winter conditions. We 
believe that intensifying efforts for public education and efficient control of resources of poisoning are the key steps to prevent carbon monoxide poisoning.

\section{ACKNOWLEDGEMENTS}

We received no funding for this study. All named authors meet the ICMJE criteria for authorship for this manuscript, take responsibility for the integrity of the work as a whole, and have given final approval to the version to be published. We declare no conflict of interest. Our study was approved by Ethics Committee of Sivas Cumhuriyet University (Project No. 201212/09) in 04.12.2012. This article does not contain any new studies with human or animal subjects performed by any of the authors.

\section{REFERENCES}

1. Aksu N, Akkas M, Coskun F, et al. Could vital signs predict carbon monoxide poisoning? J Int Med Res. 2012; 40(1): 366-70.

2. Sever H, Ikizceli I, Avsarogullari L, et al. Carbonmonoxide poisoning among patients presenting with nonspesific symptoms to the emergency department. Turk J Emerg Med. 2005; 5(1): 18-21.

3. Annane D, Chadda K, Gajdos P, Jars-Guincestre MC, Chevret S, Raphael JC. Hyperbaric oxygen therapy for acute domestic carbon monoxide poisoning: two randomized controlled trials. Intensive Care Med. 2011; 37(3): 486-92.

4. Patrick M, Fiesseler F, Shih R, Riggs R, Hung O. Monthly variations in the diagnosis of carbon monoxide exposures in the emergency department. Undersea Hyperb Med. 2009; 36(3): 161-7.

5. Metin S, Yildiz S, Cakmak T, Demirbas S. Frequency of carbon monoxide poisoning in Turkey in 2010. TAF Prev Med Bull. 2011; 10(5): 587-92.
6. Cevik Y, Tanriverdi F, Delice O, Kavalci C, Sezigen S. Reversible increases in QT dispersion and $\mathrm{P}$ wave dispersion during carbon QT. Hong Kong J Emerg Med. 2010; 17(5): 441-50.

7. Kavalci G, Arslan ED, Kavalci C, et al. The value of serum brain natriuretic peptide for hyperbaric oxygen treatment in $\mathrm{CO}$ poisoning. Health MED. 2013; 7(3): 966-70.

8. Abass MA, Arafa MH, El-Shal AS, Atteia HH. Asymmetric dimethylarginine and heart-type fatty acid-binding protein 3 are risk markers of cardiotoxicity in carbon monoxide poisoning cases in Zagazig university hospitals. Hum Exp Toxicol. 2016 May 5. pii: 0960327116646621. [Epub ahead of print] PubMed PMID: 27150386.

9. Henry CR, Satran D, Lindgren B, Adkinson C, Nicholson CI, Henry TD. Myocardial injury and long-term mortality following moderate to severe carbon monoxide poisoning. JAMA. 2006; 295(4): 398-402.

10. El Sayed M, Tamim H. Carbon monoxide poisoning in Beirut, Lebanon: Patient's characteristics and exposure sources. J Emerg Trauma Shock. 2014; 7(4): 280-4.

11. Ghosh RE, Close R, McCann LJ, et al. Analysis of hospital admissions due to accidental non-firerelated carbon monoxide poisoning in England, between 2001 and 2010. J Public Health (Oxf). 2016; 38(1): 76-83.

12. Emami-Razavi SH, Ghajarzadeh M, Aziz S, Keyvan A, Mirjafari SA, Sodagari F. Are Iranians aware of carbon monoxide poisoning: symptoms and its prevention strategies? Acta Medica Iranica. 2014; 52(12): 931-4.

13. $\mathrm{Ku} \mathrm{CH}$, Hung HM, Leong WC, et al. Outcome of patients with carbon monoxide poisoning at a fareast poison center. PLoS One. 2015; 10(3): e0118995. 